\title{
Differential Mechanisms of Morphine Antinociceptive Tolerance Revealed in BArrestin-2 Knock-Out Mice
}

\author{
Laura M. Bohn, ${ }^{1}$ Robert J. Lefkowitz, ${ }^{2}$ and Marc G. Caron ${ }^{1}$ \\ Howard Hughes Medical Institute Laboratories, Departments of ${ }^{1}$ Cell Biology and ${ }^{2}$ Biochemistry and Medicine, Duke \\ University Medical Center, Durham, North Carolina 27710
}

\begin{abstract}
Morphine induces antinociception by activating $\mu$ opioid receptors ( $\mu \mathrm{ORs})$ in spinal and supraspinal regions of the CNS. Barrestin-2 (ßarr2), a G-protein-coupled receptor-regulating protein, regulates the $\mu \mathrm{OR}$ in vivo. We have shown previously that mice lacking $\beta$ arr2 experience enhanced morphineinduced analgesia and do not become tolerant to morphine as determined in the hot-plate test, a paradigm that primarily assesses supraspinal pain responsiveness. To determine the general applicability of the $\beta$ arr2- $\mu$ OR interaction in other neuronal systems, we have, in the present study, tested $\beta$ arr2 knock-out (ßarr2-KO) mice using the warm water tailimmersion paradigm, which primarily assesses spinal reflexes to painful thermal stimuli. In this test, the Barr2-KO mice have greater basal nociceptive thresholds and markedly enhanced sensitivity to morphine. Interestingly, however, after a delayed
\end{abstract}

The regulation of G-protein-coupled receptor (GPCR) signaling can determine the extent of drug effect. In the continued presence of agonist, GPCR signaling is curtailed by a process of desensitization that results in a disrupted signal to the principal secondary messenger cascade. In the classic sense, GPCR desensitization results after the GPCR is uncoupled from its G-protein. Desensitization occurs when agonist-stimulated receptor is phosphorylated by a GPCR kinase (GRK) and then attracts an arrestin protein (Ferguson et al., 1998; Krupnick and Benovic, 1998; Lefkowitz, 1998). The arrestin binds to the phosphorylated receptor and thereby acts as a damper to prevent further coupling of the receptor with the G-protein. Several reports have demonstrated the importance of GRKs and arrestins in determining GPCR signaling in cell cultures, where it has been shown that certain GRKs and arrestins can affect GPCR desensitization. For example, the overexpression of GRK2 leads to greater phosphorylation and desensitization of rat $\mu$ opioid receptors ( $\mu \mathrm{ORs}$ ), whereas an overexpression of $\beta$ arrestin ( $\beta$ arr) can increase the internalization of the $\mu \mathrm{OR}$ in transfected cell systems (Whistler and von Zastrow, 1998; Zhang et al., 1998).

To gain a greater understanding of the contribution of $\beta$ arr2 to opioid receptor signaling, we tested the effects of morphine in

\footnotetext{
Received June 18, 2002; revised Sept. 19, 2002; accepted Sept. 20, 2002.

This work was supported by the National Institutes of Health, National Institute on Drug Abuse Grants DA-14600 (L.M.B) and DA-13115 (M.G.C.). M.G.C. and R.J.L are investigators of the Howard Hughes Medical Institute. We thank S. Suter for care and genotyping of the mouse colony and L. Dykstra and R. Gainetdinov for constructive reading of this manuscript.

Correspondence should be addressed to Dr. Marc G. Caron, Duke University Medical Center, Box 3287, Room 487 CARL, Research Drive, Durham, NC 27710. E-mail: m.caron@cellbio.duke.edu.

Copyright (C) 2002 Society for Neuroscience 0270-6474/02/2210494-07\$15.00/0
}

onset, they do ultimately develop morphine tolerance, although to a lesser degree than the wild-type (WT) controls. In the Barr2-KO but not WT mice, morphine tolerance can be completely reversed with a low dose of the classical protein kinase $\mathrm{C}(\mathrm{PKC})$ inhibitor chelerythrine. These findings provide in vivo evidence that the $\mu \mathrm{OR}$ is differentially regulated in diverse regions of the CNS. Furthermore, although $\beta$ arr2 appears to be the most prominent and proximal determinant of $\mu \mathrm{OR}$ desensitization and morphine tolerance, in the absence of this mechanism, the contributions of a PKC-dependent regulatory system become readily apparent.

Key words: morphine; $\mu$ opioid receptor; MOP; knock-out mice; Barrestin; desensitization; G-protein-coupled receptors; tolerance; antinociception

mice lacking $\beta$ arr2. $\beta$ arr2-knock-out ( $\beta$ arr2-KO) mice experience enhanced and prolonged antinociception in the $56^{\circ} \mathrm{C}$ hot-plate test after morphine treatment compared with their wild-type (WT) littermates (Bohn et al., 1999). Furthermore, these mice do not develop tolerance to morphine after acute or chronic treatment in this test of pain perception, yet they still develop morphine dependence (Bohn et al., 2000b). These observations indicate that at least in this nociception paradigm, functional desensitization of the $\mu \mathrm{OR}$ is required for development of tolerance to morphine, whereas morphine dependence can be dissociated from desensitization and tolerance.

The opioid regulation of pain perception involves $\mu \mathrm{ORs}$ in both spinal and supraspinal regions of the CNS (for review, see Cesselin et al., 1999; Heinricher and Morgan, 1999). The spinal and supraspinal action of opioids are both believed to contribute significantly to hot-plate responses, although the supraspinal system is thought to be the more prominent contributor. The spinal action of opioids is believed to contribute to the spinal reflex demonstrated by rapid tail withdrawal from a heat source (i.e., a tail flick). The spinal reflex associated with pain perception is usually tested as the latency of time passed before the tail is withdrawn. Mice that lack the $\mu \mathrm{OR}$ no longer experience morphine antinociception in either of these tests, indicating that the $\mu \mathrm{OR}$ is primarily responsible for mediating morphine antinociception (Sora et al., 1997; Kieffer 1999). Regulation of the $\mu \mathrm{OR}$ is therefore an attractive target for affecting the degree of antinociception and tolerance induced by morphine. The overall manifestation of morphine-induced antinociception and tolerance undoubtedly involves complex neuronal interactions and many different signaling components. As an example, there is much evidence that the activation of PKC may play an integral part in 
the development of morphine antinociceptive tolerance (Mayer and Price, 1976; Narita et al., 1995; Li and Roerig, 1999; Granados-Soto et al., 2000; Inoue and Ueda, 2000; Zeitz et al., 2001). Furthermore, the extent of $\mu \mathrm{OR}$ desensitization in different brain regions of the rat was shown to differ after chronic morphine treatment, suggesting that the receptor could be differentially regulated (Noble and Cox, 1996). By using mice that lack an essential component of the desensitization process, $\beta$ arr2, we are able to assess the contribution of this and other mechanisms to the antinociceptive actions of morphine in various pain perception paradigms. It is becoming increasingly apparent that the regulation of a particular receptor may differ depending on its cellular environment, be it different regions of the nervous system or within different cell types. Using this model, we now demonstrate that the spinal antinociceptive actions of morphine are regulated by $\beta$ arr2- and $\mathrm{PKC}$-dependent pathways, suggesting that, within the spinal system, both of these regulatory mechanisms contribute to $\mu \mathrm{OR}$ regulation.

\section{MATERIALS AND METHODS}

Animals and drugs. The WT mice, heterozygotes, and knock-out mice are generated as littermates from crossing heterozygous $\beta$ arr2 C57BL/6/ $129 \mathrm{SvJ}$ animals (over nine generations) as described previously (Bohn et al., 1999). Mice used in this study were age-matched, 3- to 5-month-old male siblings weighing between 20 and $35 \mathrm{gm}$. In all experiments, WT littermates served as controls for the $\beta$ arr $2+/-$ and $\beta$ arr2-KO mice, and all genotypes were evaluated simultaneously. Groups of mice were only used in the individual experiments indicated. To prevent damage to the tail, genotyping was performed on DNA extracted for tissue punched from the ear of each mouse. Experiments were conducted in accordance with National Institutes of Health Guidelines for the Care and Use of Laboratory Animals and with an approved animal protocol from the Duke University Animal Care and Use Committee. Morphine sulfate and naltrindole were purchased from Sigma (St. Louis, MO) and freshly prepared in saline and water, respectively. Naltrexone (NTX) and norbinaltorphamine (nor-BNI) were purchased from Tocris Cookson (Ballwin, MO) and freshly prepared in water. Chelerythrine chloride (Calbiochem, San Diego, CA) was freshly prepared in DMSO and diluted for a final injection volume in water at $2 \%$ DMSO. All compounds were injected at a volume of $10 \mu \mathrm{l} / \mathrm{gm}$ animal weight.

Warm water tail-immersion assay. Antinociception was evaluated by measuring response latencies in the warm water tail-immersion (tailflick) assay (Janssen et al., 1963; Stone et al., 1997). Response latencies were measured as the amount of time the animal took to respond to the thermal stimuli. The warm water $\left(43,48\right.$, and $\left.54^{\circ} \mathrm{C}\right)$ tail-flick test was performed by gently holding the mouse in a terry cloth towel and immersing between 2 and $3 \mathrm{~cm}$ from the tip of the tail into the water, and the response was defined as the removal of the tail from the warm water as described previously (Bohn et al., 2000c). Hot-plate $\left(50,53\right.$, and $\left.56^{\circ} \mathrm{C}\right)$ experiments were performed as described previously (Bohn et al., 1999). When exposed to the test under the influence of morphine, mice were not permitted to exceed $30 \mathrm{sec}$ of exposure to the thermal source to prevent prolonged painful stimulation. The reported data account for this artificial ceiling as well as for the basal responsiveness of each mouse to the test and is presented as the percentage of maximum possible effect (\%MPE), which is calculated by the following formula: $100 \% \times[$ drug response time - basal response time $) /(30 \mathrm{sec}-$ basal response time $)]=$ $\%$ MPE.

$\left.{ }^{35} \mathrm{~S}\right]$ GTP $\gamma S$ binding assays. $\left[{ }^{35} \mathrm{~S}\right] \mathrm{GTP} \gamma \mathrm{S}(1250 \mathrm{Ci} / \mathrm{mmol}$; NEN, Boston, MA) binding assays were performed on membranes from mouse spinal cords as described previously (Bohn et al., 1999). Samples were placed on ice and homogenized by polytron in membrane preparation buffer (50 mM Tris, pH 7.4, $1 \mathrm{~mm}$ EDTA, and $3 \mathrm{~mm} \mathrm{MgCl}_{2}$ ), and crude membranes were prepared by centrifugation at $20,000 \times g$ for $30 \mathrm{~min}$ at $4^{\circ} \mathrm{C}$. Membranes were resuspended in assay buffer $(50 \mathrm{~mm}$ Tris- $\mathrm{HCl}, \mathrm{pH}$ 7.4, $100 \mathrm{~mm} \mathrm{NaCl}, 3 \mathrm{~mm} \mathrm{MgCl}$, and $0.2 \mathrm{~mm}$ EDTA) containing $10 \mu \mathrm{M}$ GDP. Reactions were terminated by rapid filtration over GF/B filters (Brandel, Gaithersburg, MD) using a Brandel cell harvester. Filters were washed three times with ice-cold $10 \mathrm{~mm}$ Tris- $\mathrm{HCl}, \mathrm{pH} 7.4$, and then counted in a liquid scintillation counter. $n$ represents membranes prepared from striata from one mouse.
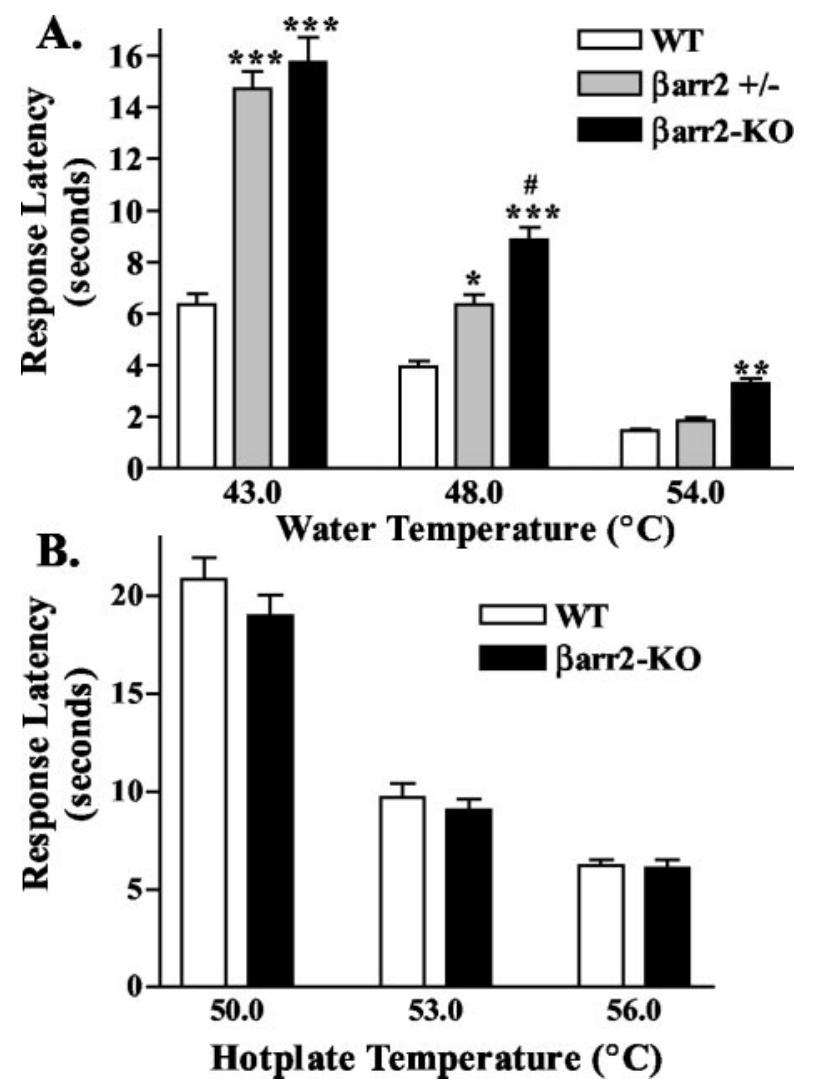

Figure 1. Basal tail-flick but not hot-plate response latencies are prolonged in $\beta$ arr2-KO mice. $A$, Tail flick. Mice of each genotype were assessed for their responsiveness in the warm water tail-flick assay. Response latencies were assessed at 43,48 , and $54^{\circ} \mathrm{C}$ water temperatures; ${ }^{*} p<0.05,{ }^{* *} p<0.01$, and ${ }^{* * *} p<0.001$ versus $\mathrm{WT}$; ${ }^{*} p<0.05$ versus $\beta$ arr2+/-; one-way ANOVA followed by Bonferroni's multiple comparison test; $n=13-20 \mathrm{WT} ; n=6-8 \beta \operatorname{arr} 2+/-; n=13-21 \beta$ arr2-KO mice. $B$, Hot-plate. WT and $\beta$ arr2-KO mice were assessed for paw-withdrawal latencies on the 50,53 , and $56^{\circ} \mathrm{C}$ hot plate. There were no differences in responses between the littermates $(n=12-27)$.

Statistical analysis. All statistical analyses were calculated using GraphPad (San Diego, CA) Prism software.

\section{RESULTS}

\section{Basal nociceptive thresholds}

Basal response latencies were assessed using the warm water tail-immersion test, and a difference between genotypes became readily apparent. At 43,48 , and $54^{\circ} \mathrm{C}$, the $\beta$ arr2-KO mice experience a significantly greater delay in tail withdrawal than their WT counterparts (Fig. 1A). Furthermore, this delay in tail withdrawal is also greater in the $\beta$ arr2 heterozygotes, implicating the importance of the concentration of $\beta$ arr2 in regulating $\mu \mathrm{OR}$ responsiveness (Zhang et al., 1998; Lowe et al., 2002). The initial comparison of basal nociception to the $56^{\circ} \mathrm{C}$ hot-plate revealed that the WT and $\beta$ arr2-KO mice did not differ in their response latencies (Bohn et al., 1999), and this observation has been extended to hot-plate temperatures of 50 and $53^{\circ} \mathrm{C}$ as well (Fig. $1 B$ ) where again, no differences are seen. The prolonged tail-flick latencies in the $\beta$ arr2-KO mice come somewhat unexpectedly, considering that there are no differences between genotypes observed in the hot-plate test. Furthermore, the elevated tail-flick latencies were also present in $\beta$ arr2-KO mice that had been back-crossed six generations to C57BL/6 mice (C57-WT, $1.8 \pm$ $0.34 \mathrm{sec}$; C57-KO, $4.5 \pm 0.3 \mathrm{sec}$ ), exemplifying the penetrance and 


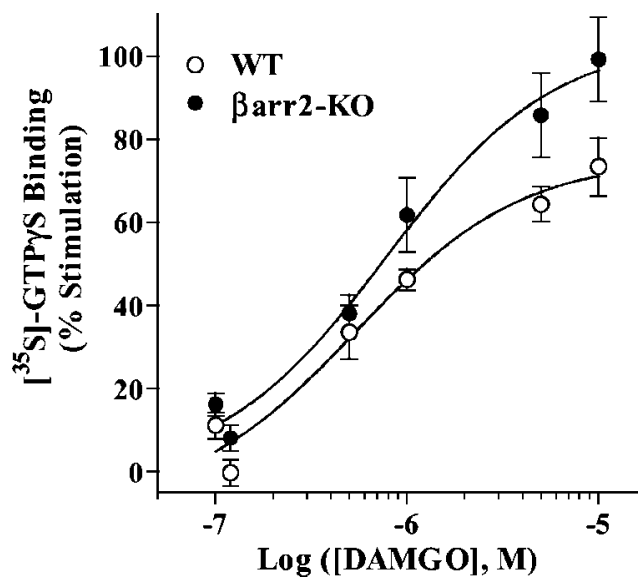

Figure 2. Enhanced $\mu \mathrm{OR}$ coupling to G-proteins in spinal cord membranes from $\beta$ arr2-KO mice. Data were analyzed by nonlinear regression using GraphPad Prism software and are presented as the mean \pm SEM of four experiments performed in triplicate, wherein WT and $\beta$ arr2-KO spinal cord membranes were assayed simultaneously. The percentage of agonist-stimulated binding over basal is expressed. In the absence of agonist stimulation, basal $\left[{ }^{35} \mathrm{~S}\right] \mathrm{GTP} \gamma \mathrm{S}$ binding was as follows: WT, $1835 \pm 251 \mathrm{cpm} ; \beta$ arr2-KO, $1675 \pm 223 \mathrm{cpm}$. The curves are significantly different $(p<0.001)$ compared with two-way ANOVA. DAMGO, D-Ala ${ }^{2}-N$-Me-Phe ${ }^{4}-$ Glycol $^{5}$ ]enkephalin.

significance of the differences seen between the genotypes in the tail-flick test.

\section{$\left[{ }^{35} \mathrm{~S}\right] \mathrm{GTP} \gamma \mathrm{S}$ binding in spinal cord membranes}

GPCR coupling to G-protein is an indicator of the potential of the receptor to signal. Therefore, we assessed $\mu \mathrm{OR}$ coupling in membranes prepared from mouse spinal cord. The $\mu \mathrm{OR}$-selective agonist D-Ala ${ }^{2}-N$-Me-Phe ${ }^{4}-$ Glycol $^{5}$ ]enkephalin showed a robust stimulation of G-protein coupling in the WT mouse membranes; however, there was a greater degree of agonist-dependent coupling in the spinal cord membranes from the $\beta$ arr2-KO mice (Fig. 2). Radioligand binding assays in spinal cord membranes using $\left[{ }^{3} \mathrm{H}\right]$ naloxone $(52 \mathrm{Ci} / \mathrm{mmol}$; Amersham Biosciences, Piscataway, NJ) showed no difference between genotypes in receptor binding (data not shown). It appears that this enhanced coupling of the $\mu \mathrm{OR}$ in the $\beta$ arr2-KO mice correlates with the enhanced basal antinociception seen in the tail-immersion test. However, it should be noted that an enhanced coupling of the $\mu \mathrm{OR}$ was also detected in periaqueductal gray and brainstem regions of the mutant mice, and this was not reflected in differences in basal pain perception as assessed in the hot-plate test (Bohn et al., 1999, 2000b). This apparent difference in the behavioral outcome could reflect a more complex circuitry underlying central pain processing systems.

\section{Antagonism of basal antinociception}

To assess whether the increased tail-withdrawal latency was mediated via the $\mu \mathrm{OR}$, mice were treated with opioid receptor antagonists. Naltrexone ( $2 \mathrm{mg} / \mathrm{kg}$, i.p.) was used to reverse the tail-flick latencies of the $\beta$ arr2-HT and $-\mathrm{KO}$ mice to the same levels experienced by the WT mice (Fig. $3 A$ ). This effect was also seen at water temperatures of 42 and $54^{\circ} \mathrm{C}$ (data not shown). Furthermore, a fourfold lower dose of naltrexone reduced tailflick latencies in the $\beta$ arr2-KO mice (KO basal, $7.8 \pm 1.2 ; \mathrm{KO}$ plus NTX, $4.2 \pm 0.2 \mathrm{sec} ; n=7)$, whereas WT mice were not affected by this dose (WT basal, $4.4 \pm 0.8$; WT plus NTX, $4.3 \pm 0.3 \mathrm{sec}$; $n=7)$. Naltrexone blocks $\mu, \delta$, and $\kappa$ opioid receptors; however, because there is not a highly selective $\mu \mathrm{OR}$ antagonist that can be administered systemically, it was used in parallel with antagonists selective for $\delta$ or $\kappa$ opioid receptors (Negus et al., 1993). Naltrindole ( $\delta$ selective; $2.5 \mathrm{mg} / \mathrm{kg}$, s.c.) and nor-binaltorphamine $(\kappa$ selective; $5 \mathrm{mg} / \mathrm{kg}$, s.c.), which inhibit $\delta$ - and $\kappa$-mediated antinociception (Matthes et al., 1998), did not affect the basal tail-flick latencies in either genotype (Fig. $3 B$ ), demonstrating that the enhanced basal antinociception is mediated through the $\mu \mathrm{OR}$.

\section{Morphine-induced antinociception}

The $\beta$ arr2-KO mice display an increased sensitivity to morphine in the hot-plate antinociception test (Bohn et al., 1999); therefore, morphine-induced antinociception was assessed in the tailimmersion test as well. Again, $\beta$ arr2-KO mice experience a more prolonged and enhanced antinociceptive response compared with WT littermates after a single morphine $(10 \mathrm{mg} / \mathrm{kg}$, s.c. $)$ injection (Fig. 4). The data have been normalized to the basal latency and the artificial ceiling of $30 \mathrm{sec}$ to prevent overexposure of the tail to the warm water. By normalizing to the basal latency of each mouse, the effect of morphine can be considered over the differences already seen in the basal latencies. Furthermore, the tests with morphine were conducted at $54^{\circ} \mathrm{C}$, a temperature at which the smallest differences between $\mathrm{WT}$ and $\beta$ arr2-KO mice are seen.

\section{Morphine-induced antinociceptive tolerance}

A disruption of $\mu \mathrm{OR}$ desensitization by elimination of $\beta$ arr2 results in a lack of morphine antinociceptive tolerance in the hot-plate test, as demonstrated previously in the $\beta$ arr2-KO mice (Bohn et al., 2000b). This lack of antinociceptive tolerance was apparent in three separate regimens of morphine treatment, which demonstrated that the $\beta$ arr2-KO mice do not become tolerant after an acute challenge of a large dose of morphine, nor do they develop tolerance after chronic administration of the drug. The underlying circuitry regulating the perception of pain in the warm water tail-immersion and hot-plate tests is likely to differ (LeBars et al., 1976; Mayer and Price, 1976; Mansour et al., 1988; Yaksh, 1997). Moreover, the contribution of $\beta$ arr2 to each of these systems may also differ, as can be observed in their basal pain response latencies in the two tests, wherein the mutant mice only displayed an increased latency in the tail-flick test. Given the potential for differences in the regulation of these systems, the development of morphine tolerance was also evaluated in the tail-immersion test.

Twenty-four hours after an acute challenge with either saline or a high dose of morphine $(100 \mathrm{mg} / \mathrm{kg}$, s.c. $)$, mice were assessed for their responsiveness to the $54^{\circ} \mathrm{C}$ water tail immersion $30 \mathrm{~min}$ after morphine $(10 \mathrm{mg} / \mathrm{kg}$, s.c.) treatment. As was observed previously in the hot-plate test, the WT mice develop substantial tolerance to subsequent morphine treatment, whereas the Barr2-KO mice experience the full antinociceptive effects of morphine in the tail-immersion test regardless of whether they received saline or a large dose of morphine the day before (Fig. 5). This absence of the development of acute morphine tolerance suggests that, as in the hot-plate test, $\beta$ arr 2 plays an essential role in regulating $\mu \mathrm{OR}$ responsiveness in the development of acute tolerance.

The mechanisms underlying the development of acute and chronic morphine tolerance have been considered to be the same (Fairbanks and Wilcox, 1997). However, when considering tolerance in direct relation to desensitization of the receptor, the development of acute tolerance is likely to be fundamentally 

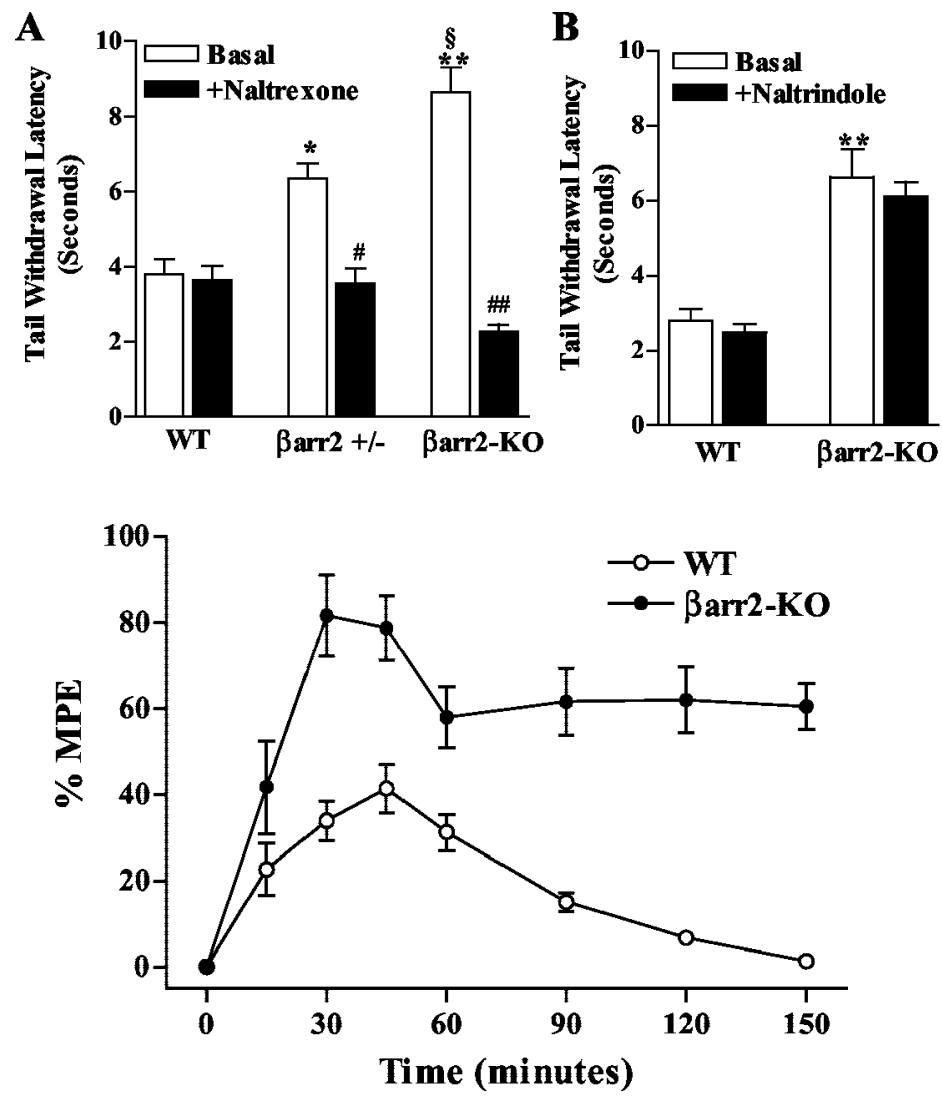

Figure 4. Morphine induces enhanced and prolonged tail-flick latencies in $\beta$ arr2-KO mice. Morphine $(10 \mathrm{mg} / \mathrm{kg}$, s.c.) was injected, and tailwithdrawal latencies were recorded $15,30,45,60,90$, and 120 min later $\left(54^{\circ} \mathrm{C}\right.$ water $)$. The genotypes are significantly different $(p<0.0001)$ by two-way ANOVA; $n=7$ mice per genotype.

different from chronic tolerance caused by the desensitization requirements of a repeated low dose of drug versus an immediate need to compensate for a single challenge with an extremely high concentration of drug. The cellular adaptations required to compensate for the challenge of a high concentration of drug might differ at the receptor level from the cellular adaptations required to compensate for repeated administrations of a lower dose of drug. Therefore, we treated animals with morphine $(10 \mathrm{mg} / \mathrm{kg}$, s.c.) on a daily basis and monitored their responsiveness in the tail-immersion test. Although the onset of morphine tolerance is readily apparent in WT mice after the third day of morphine treatment, the $\beta$ arr2-KO mice still experience the full effect of morphine over this period. Interestingly, after the fourth day of treatment, the $\beta$ arr2-KO mice abruptly begin to lose their sensitivity to morphine (Fig. $6 A$ ). By the fifth day, the $\beta$ arr2-KO mice are no different from the $\mathrm{WT}$ mice in their responsiveness to morphine, and both mice appear to be completely tolerant to morphine $(10 \mathrm{mg} / \mathrm{kg}$, s.c. $)$ in the tail-immersion test throughout the seventh day. This was surprising, because the $\beta$ arr2-KO mice failed to develop morphine tolerance even after $9 \mathrm{~d}$ of consecutive morphine administration in the hot-plate test paradigm. In this experiment, the same mice that showed no responsiveness to morphine in the tail-immersion test on the seventh day were also subjected to the $56^{\circ} \mathrm{C}$ hot-plate test. Although the $\beta$ arr2-KO mice experience tolerance in the tail-immersion test, they still experience the antinociceptive effects of morphine in the hot-plate test (Fig. 6A, inset).

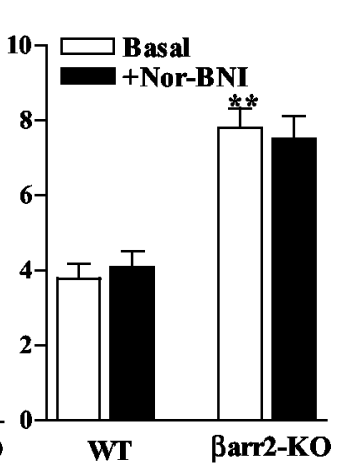

Figure 3. Antagonist reversal of enhanced basal tail-flick latencies. Antagonists were injected 20 min before the tail-flick test was performed. Water temperature was $48^{\circ} \mathrm{C}$. $A$, Naltrexone $(2 \mathrm{mg} / \mathrm{kg}$, i.p. $)$ antagonizes tailflick latencies of $\beta$ arr2-KO and $\beta$ arr2 $+/-$ to that experienced by WT mice. $B$, Naltrindole $(2.5 \mathrm{mg} / \mathrm{kg}$, s.c. $)$ and nor-BNI $(5 \mathrm{mg} / \mathrm{kg}$, s.c. $)$ did not affect the enhanced latencies seen in the $\beta$ arr2-KO mice; * $p<0.01$ and ${ }^{* *} p<$ 0.001 versus WT basal; ${ }^{\#} p<0.01$ and ${ }^{\$} p<$ 0.05 versus $\beta$ arr $2+/-$ basal; and ${ }^{\# \#} p<0.001$ versus $\beta$ arr2-KO basal; one-way ANOVA followed by Bonferroni's multiple comparison test; $n=6-8$ mice per genotype.

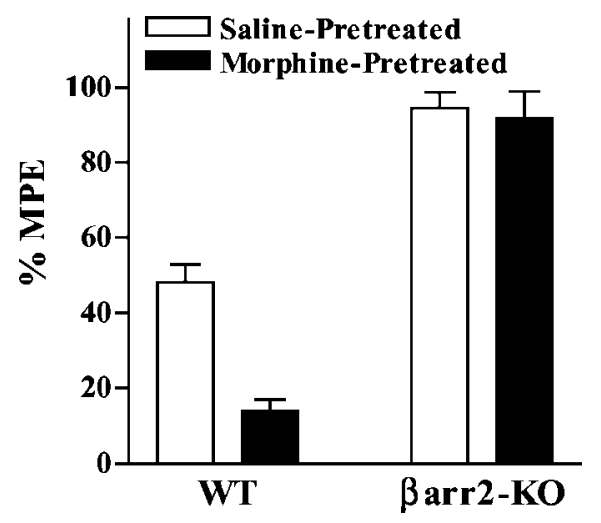

Figure 5. $\quad \beta$ arr2-KO mice do not develop acute morphine tolerance. Mice were pretreated with either saline or morphine $(100 \mathrm{mg} / \mathrm{kg}$, s.c.), and 24 hr later, when they had returned to their basal latencies, mice were administered morphine $\left(10 \mathrm{mg} / \mathrm{kg}\right.$, s.c.). Tail-withdrawal latencies $\left(54^{\circ} \mathrm{C}\right.$ water) were assessed $30 \mathrm{~min}$ after this second injection. Although the WT mice experience tolerance $24 \mathrm{hr}$ after receiving the first injection of morphine ( $p<0.001$ compared with saline pretreatment), the $\beta$ arr2-KO mice do not. The $\beta$ arr2-KO mice experience greater antinociception after morphine than WT mice regardless of whether they were pretreated with morphine or saline $(p<0.001)$. Analysis is by one-way ANOVA followed by Bonferroni's multiple comparison test; $n=6$ mice per genotype.

To ascertain whether there is a difference in the degree of tolerance developed between genotypes, a dose-response curve was generated on days 1 and 7 of the chronic morphine tailimmersion regimen (Fig. $6 B$ ). On day 1, it is apparent that the Barr2-KO mice are approximately twofold more sensitive to morphine than the WT mice; this observation was also consistent with the hot-plate test results (Bohn et al., 2000b). However, after chronic morphine treatment, the knock-out mice have developed morphine tolerance, as have the WT mice. Although the ßarr2-KO mice, like the WT mice, experience tolerance to morphine, the concentration required to reach half-maximal antinociception in the WT mice was considerably higher than in the mutant mice. This suggests that although the $\beta$ arr2-KO mice have become tolerant in the tail-flick assay, they have not reached the same extent of tolerance as the WT mice.

By examining the antinociceptive properties of morphine using the hot-plate and tail-immersion paradigms, we find that in both cases, mice lacking $\beta$ arr2 are more sensitive to morphine. After chronic morphine treatment, $\beta$ arr2-KO mice do not develop tolerance to the hot plate; however, they do experience tolerance, albeit to a lesser extent, in the tail-immersion test. These differences suggest that perhaps in the spinal reflex test, there is another, $\beta$ arr2-independent regulatory mechanism that might contribute to the modulation of morphine-induced antinocicep- 

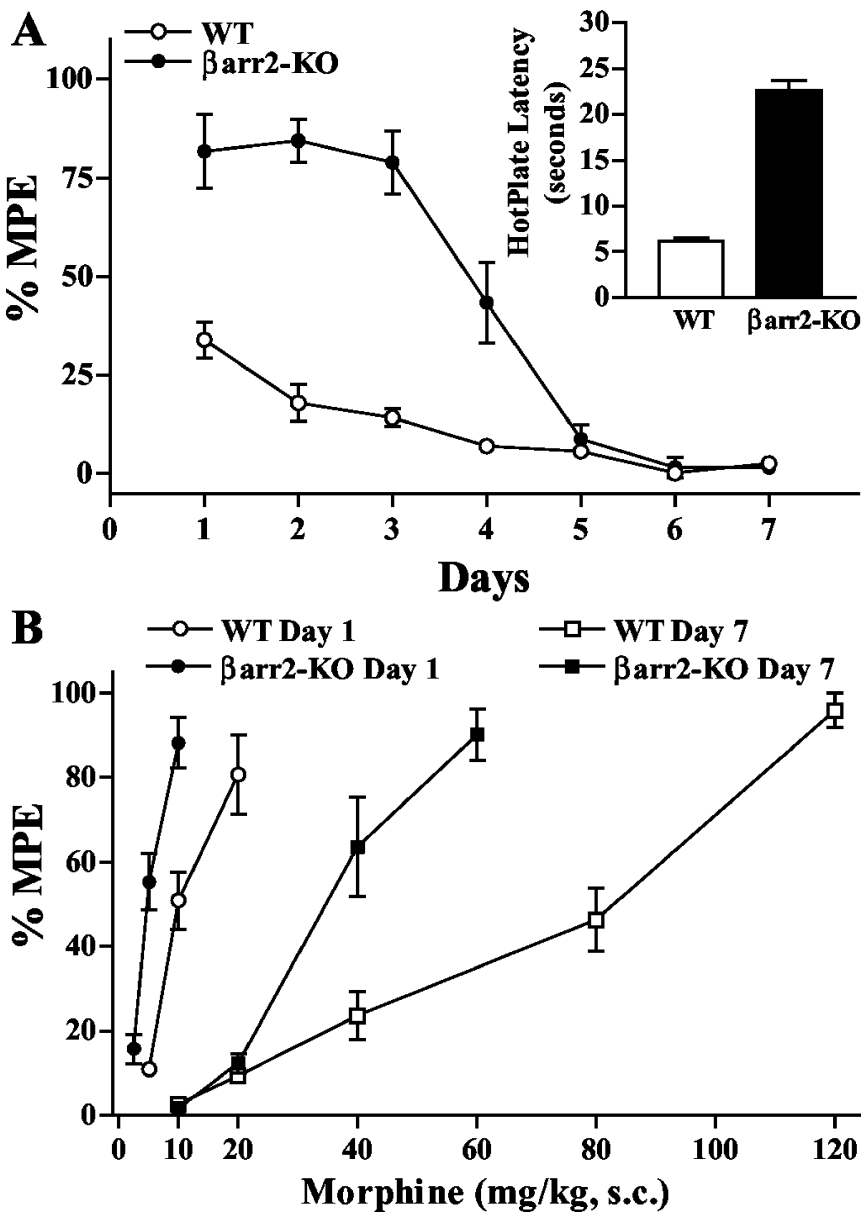

Figure 6. Chronic morphine tolerance in WT and $\beta$ arr2-KO mice. $A$, Mice received morphine $(10 \mathrm{mg} / \mathrm{kg}$, s.c. $)$ each day; $30 \mathrm{~min}$ later, tail-flick latencies were recorded $\left(54^{\circ} \mathrm{C}\right.$ water). $\beta$ arr2-KO experience significantly enhanced morphine antinociception compared with WT mice for the first $4 \mathrm{~d}\left({ }^{*} p<0.001 ;{ }^{\#} p<0.005\right)$, with a significant decrease on days 4 and 5 $(p<0.02)$. Student's $t$ test; $n=7$ mice per genotype. Inset, On day 7, mice were placed on the hot plate $\left(56^{\circ} \mathrm{C}\right)$, and paw-withdrawal latencies were recorded. $B$, A morphine dose-response curve was generated in animals on day 1 and again after $7 \mathrm{~d}$ of daily morphine treatments. In these studies, mice were not tested daily for antinociceptive latencies. Some points at the lower doses are the averaged responses after cumulative dosing of morphine as described previously (Bohn et al., 2000a). These points were similar to results obtained with an acute dose of the drug and were therefore averaged together. $\mathrm{ED}_{50}$ values were calculated via nonlinear regression analysis (GraphPad Prism), and 95\% confidence intervals are as follows: day $1 \mathrm{WT}, 10.3$ (7.6-13.7); $\beta$ arr2-KO, 4.6 (4.5-4.8); day $7 \mathrm{WT}, 75.8$ (51.3-112.1); $\beta$ arr2-KO, 34.5 (33.8-35.3) mg/kg.

tion. The concept that other regulatory components could contribute to desensitizing the receptor after chronic morphine is attractive and perhaps consistent with the delayed onset of tolerance until the fourth day of treatment. Moreover, mechanisms other than classical $\mu \mathrm{OR}$ desensitization have been suggested previously for the development of morphine tolerance. However, the $\beta$ arr2-KO mice do not develop the same degree of tolerance as the WT mice, suggesting that the $\beta$ arr2-mediated desensitization of the receptor may be the predominant mechanism, yet other contributions to morphine tolerance clearly must be present.

\section{Reversal of morphine tolerance in knock-out mice}

One potential mechanism involves PKC activation, which has been shown to contribute to $\mu \mathrm{OR}$ responsiveness. In several studies, PKC inhibitors have been used to block the development of morphine tolerance in mice (Narita et al., 1995; Granados-Soto et al., 2000; Inoue and Ueda, 2000). Because PKC inhibitors are not isoform selective, it has been difficult to attribute the actions of these inhibitors to a specific form of PKC. Recently, Zeitz et al. (2001) reported that mice lacking the PKC $\gamma$ isoform experience slightly yet significantly attenuated morphine tolerance in the tail-immersion test. The fact that the PKC $\gamma$-KO mice still experience a significant degree of tolerance could be attributable to the dominance of the still intact $\beta$ arr2-mediated desensitization of the receptor. To test whether PKC is contributing to the delayed and attenuated development of morphine tolerance in the $\beta$ arr2-KO mice, we treated mice after $7 \mathrm{~d}$ of chronic morphine (10 mg/kg, s.c., daily) with the PKC inhibitor chelerythrine. When given $10 \mathrm{~min}$ before morphine, chelerythrine was able to completely reverse morphine tolerance in the $\beta$ arr2-KO mice, while having little to no effect on the tolerant WT mice (Fig. 7A).

In previous studies in which $\mathrm{PKC}$ inhibitors have been reported to reverse morphine tolerance, the drug was administered intrathecally (Granados-Soto et al., 2000; Inoue and Ueda, 2000) or intracerebroventricularly (Smith et al., 1999). In the present study, the dose of chelerythrine $(5 \mathrm{mg} / \mathrm{kg})$ was given intraperitoneally; therefore, it is not surprising that the low concentration of the inhibitor reaching the spinal sites is not sufficient to reverse tolerance in the WT mice, wherein the $\beta$ arr2-mediated desensitization remains intact. The effect of chelerythrine alone was also tested in tolerant and naive animals. Chelerythrine did not affect tail-withdrawal latencies in either genotype when given alone to tolerant mice (Fig. 7A). To verify that chelerythrine does not synergize with morphine to produce antinociception in the $\beta$ arr2-KO mice, we tested chelerythrine with morphine $(5 \mathrm{mg} / \mathrm{kg}$, s.c.). The lower dose of morphine was chosen to ensure that in the case of synergism, the ceiling would not be reached; however, there is no effect of chelerythrine on morphine-induced antinociception (Fig. 7B). Therefore, in the absence of the $\beta$ arr2mediated desensitization, the contributions of other systems, possibly downstream of the immediate regulation of the $\mu \mathrm{OR}$, become readily apparent. Our data suggest that PKC activity contributes to the desensitization of the $\mu \mathrm{OR}$ and hence to the delayed development of morphine tolerance in the tail-flick assay in the $\beta$ arr2-KO mice.

\section{DISCUSSION}

The delayed tail-flick response latency displayed by the $\beta$ arr2-KO mice represents the first phenotype reported in the mutant mice that occurs in the absence of agonist challenge. Although the latency of the tail-flick response is prolonged in the mutant mice, the response to the hot plate remains the same between the littermates (Fig. 1). It should also be noted that there is a genedosage effect, as can be seen in the delayed tail-withdrawal responses in the heterozygotes. The enhanced tail-flick latency seen in the $\beta$ arr2-KO mice correlates with increased $\mu \mathrm{OR}-\mathrm{G}$-protein coupling in membranes prepared from spinal cord (Fig. 2), implying that the extended response latencies in the warm water tail-immersion test may be caused by increased activity at spinal $\mu$ ORs. This concept is supported by the ability of naltrexone, but not nor-BNI or naltrindole, to inhibit this effect in the knock-out animals (Fig. 3).

The $\beta$ arr2-KO mice represent an animal model in which the morphine-induced desensitization of the $\mu \mathrm{OR}$ has been significantly impaired because of the loss of $\beta$ arr2. In addition to displaying an enhanced and prolonged response to morphine in 
$\mathbf{A}$

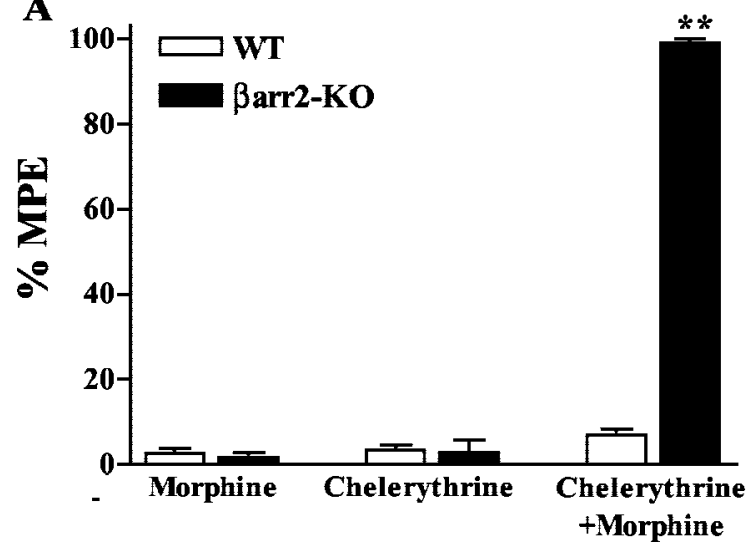

B

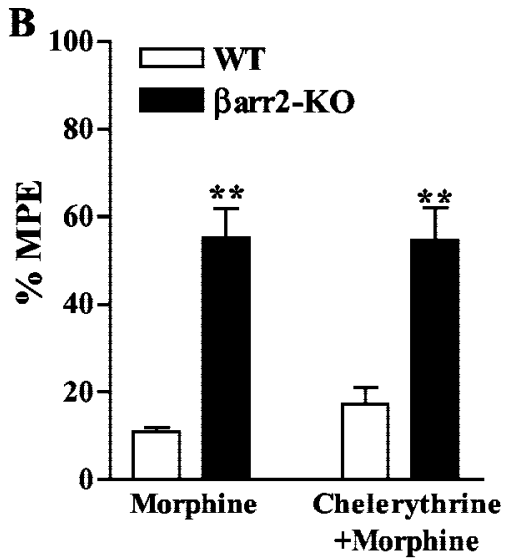

Figure 7. Chelerythrine reverses morphine tolerance in $\beta$ arr2-KO mice. $A$, Mice that had been treated for $7 \mathrm{~d}$ with morphine were then given one of the following combinations: vehicle for $10 \mathrm{~min}$ plus morphine $(10 \mathrm{mg} / \mathrm{kg}$, s.c.) for $30 \mathrm{~min}$, chelerythrine (5 $\mathrm{mg} / \mathrm{kg}$, i.p.) for $10 \mathrm{~min}$ plus vehicle for 30 $\mathrm{min}$, or chelerythrine $(5 \mathrm{mg} / \mathrm{kg}$, i.p.) for 10 min plus morphine $(10 \mathrm{mg} / \mathrm{kg}$, s.c.) for 30 $\min$. At the end of the $40 \mathrm{~min}$ total treatment time, antinociceptive latencies were tested $\left(54^{\circ} \mathrm{C}\right.$ water). ${ }^{* *} p<0.001$ versus all points; one-way ANOVA followed by Bonferroni's multiples comparison test; $n=6$ (Morphine) $n=3$ (Chelerythrine) $n=9$ (Chelerythrine + Morphine). B, Naive mice were treated with either vehicle for $10 \mathrm{~min}$ plus morphine $(5 \mathrm{mg} / \mathrm{kg}$, s.c.) for $30 \mathrm{~min}$ or chelerythrine $\left(5 \mathrm{mg} / \mathrm{kg}\right.$, i.p.) for $10 \mathrm{~min}$ plus morphine $\left(5 \mathrm{mg} / \mathrm{kg}\right.$, s.c.) for $30 \mathrm{~min}$ before antinociceptive testing. ${ }^{* *} p<0.001$ versus WT; $n=5-6$, as assessed in $A$. both hot-plate and tail-immersion tests (Fig. 4) for pain perception, the $\beta$ arr2-KO mice also do not develop acute tolerance after a single challenge of a large dose of morphine in both tests (Fig. 5). However, after chronic daily morphine administration, although the $\mathrm{KO}$ mice do not demonstrate morphine tolerance in the hot-plate test, they do develop tolerance, although to a lesser degree than WT mice, in the tail-immersion test (Fig. 6). The enhanced and prolonged antinociception after a single dose of morphine, the lack of acute tolerance in the $\beta$ arr2-KO mice, and the fact that they show no sign of decreased morphine responsiveness in the first $3 \mathrm{~d}$ of treatment suggest that $\beta$ arr 2 is predominantly involved in the normal desensitization of the $\mu \mathrm{OR}$ when drug is present. However, on the fourth day of morphine treatment, the $\beta$ arr2-KO mice show the first signs of tolerance, and by the fifth day, the mice no longer respond to $10 \mathrm{mg} / \mathrm{kg}$ morphine in the tail-immersion test. This delayed onset of the development of tolerance in the mutant mice implies the intervention of another mechanism.

There is good evidence supporting a role for PKC in morphine tolerance. Several studies have shown that PKC levels and activity are increased after chronic opiate treatment. Specifically, PKC $\alpha$ and $\mathrm{PKC} \gamma$ activity and expression were increased in rat dorsal horn membrane preparations after chronic morphine; furthermore, the increased activity could be blocked by chelerythrine after the chronic treatment (Granados-Soto et al., 2000). Li and Roerig (1999) reported enhanced PKC catalytic activity in mouse spinal cord after chronic morphine treatment. In addition, studies in mice lacking PKC $\gamma$ revealed a modest attenuation of morphine tolerance in the tail-immersion test. In these studies, because the degree of attenuation was small, these authors suggested that other PKC isoforms, which are still present in these mice, might be contributing to the induced tolerance as well. Our data suggest that perhaps the remaining tolerance expressed by the $\mathrm{PKC} \gamma-\mathrm{KO}$ mice is not simply attributable to remaining PKC activity but is much more likely the result of $\beta$ arr2-mediated desensitization of the receptors, which is still intact in these mice.

It is not known whether PKC regulation of the $\mu \mathrm{OR}$ occurs via direct phosphorylation of the receptor (Zhang et al., 1996) or whether the kinase serves as an intermediate in another neuronal signaling system. For example, increased PKC activity facilitates NMDA receptor signaling. Glutamatergic activation of NMDA receptors is involved in morphine tolerance, and the blockade of this system by NMDA receptor antagonists, such as $(+)-5-$ methyl-10,11-dihydro-5H-dibenzo [a,d] cyclohepten-5,10-imine maleate (MK-801), can attenuate the development of morphine tolerance (Trujillo and Akil, 1991; Gutstein and Trujillo, 1993; Allen and Dykstra, 1999). Fan et al. (1998) have proposed that the activation of NMDA receptors enhances PKC activation and the subsequent desensitization of opioid receptors in NG108-15 cells and in cultured neurons. PKC activation could also play a role in the $\kappa$ opioid receptor-mediated effects on tolerance (Vanderah et al., 2001), because the $\kappa$ receptor has been shown to signal through PKC (Barg et al., 1993; Bohn et al., 2000a). Although we do not know at what point PKC regulation of $\mu \mathrm{OR}$ signaling comes into play, the importance of $\beta$ arr2-mediated receptor regulation in the development of morphine tolerance is once again demonstrated. It is only in the absence of $\beta$ arr2 that the role for chelerythrine-sensitive PKC regulation of the $\mu \mathrm{OR}$ becomes readily apparent.

Mice lacking $\beta$ arr2 exhibit substantially enhanced morphine responsiveness either in the hot-plate test or the tail-immersion antinociceptive test. Our previous study demonstrated that in the absence of $\beta$ arr2, mice did not develop tolerance regardless of whether morphine was given by acute, daily chronic, or constant chronic administration (Bohn et al., 2000b). In this study, we have found that $\mu \mathrm{OR}$ response to the antinociceptive drug morphine can be alternatively regulated in different pain perception systems. It would appear that the $\beta$ arr2-mediated mechanism of desensitization is the major contributor to the development of tolerance in both supraspinal and spinal systems. However, abrogation of this dominant regulatory mechanism clearly reveals the contribution of a PKC-mediated mechanism underlying the development of morphine tolerance in spinal systems.

\section{REFERENCES}

Allen RM, Dykstra LA (1999) The competitive NMDA receptor antagonist LY235959 modulates the progression of morphine tolerance in rats. Psychopharmacology (Berl) 142:209-214.

Barg J, Belcheva MM, Rowinski J, Coscia CJ (1993) kappa-Opioid agonist modulation of $\left[{ }^{3} \mathrm{H}\right]$ thymidine incorporation into DNA: evidence for the involvement of pertussis toxin-sensitive $G$ protein-coupled phosphoinositide turnover. J Neurochem 60:1505-1511.

Bohn LM, Lefkowitz RJ, Gainetdinov RR, Peppel K, Caron MG, Lin FT (1999) Enhanced morphine analgesia in mice lacking beta-arrestin 2. Science 286:2495-2498.

Bohn LM, Belcheva MM, Coscia CJ (2000a) Mitogenic signaling via endogenous kappa-opioid receptors in C6 glioma cells: evidence for the involvement of protein kinase $\mathrm{C}$ and the mitogen-activated protein kinase signaling cascade. J Neurochem 74:564-573.

Bohn LM, Gainetdinov RR, Lin FT, Lefkowitz RJ, Caron MG (2000b) $\mathrm{Mu}$-opioid receptor desensitization by beta-arrestin- 2 determines morphine tolerance but not dependence. Nature 408:720-723. 
Bohn LM, Xu F, Gainetdinov RR, Caron MG (2000c) Potentiated opioid analgesia in norepinephrine transporter knock-out mice. J Neurosci 20:9040-9045.

Cesselin F, Benoliel J-J, Bourgoin S, Collin E, Pohl M, Hamon M (1999) Spinal mechanisms of opioid analgesia. In: Opioids in pain control: basic and clinical aspects (Stein C, ed), pp 70-95. New York: Cambridge UP.

Fairbanks CA, Wilcox GL (1997) Acute tolerance to spinally administered morphine compares mechanistically with chronically induced morphine tolerance. J Pharmacol Exp Ther 282:1408-1417.

Fan GH, Zhao J, Wu YL, Lou LG, Zhang Z, Jing Q, Ma L, Pei G (1998) $N$-Methyl-D-aspartate attenuates opioid receptor-mediated $\mathrm{G}$ protein activation and this process involves protein kinase C. Mol Pharmacol 53:684-690

Ferguson SS, Zhang J, Barak LS, Caron MG (1998) Molecular mechanisms of $\mathrm{G}$ protein-coupled receptor desensitization and resensitization. Life Sci 62:1561-1565.

Granados-Soto V, Kalcheva I, Hua X, Newton A, Yaksh TL (2000) Spinal PKC activity and expression: role in tolerance produced by continuous spinal morphine infusion. Pain 85:395-404.

Gutstein HB, Trujillo KA (1993) MK-801 inhibits the development of morphine tolerance at spinal sites. Brain Res 626:332-334.

Heinricher MM, Morgan MM (1999) Supraspinal mechanisms of opioid analgesia. In: Opioids in pain control: basic and clinical aspects (Stein C, ed), pp 46-69. New York: Cambridge UP.

Inoue M, Ueda $\mathrm{H}$ (2000) Protein kinase C-mediated acute tolerance to peripheral mu-opioid analgesia in the bradykinin-nociception test in mice. J Pharmacol Exp Ther 293:662-669.

Janssen PA, Niemegeers CJE, Dony JGH (1963) The inhibitory effect of fentanyl and other morphine-like analgesics on the warm water induced tail withdrawal reflex in rats. Arzneimittelforschung 13:502-507.

Kieffer BL (1999) Opioids: first lessons from knockout mice. Trends Pharmacol Sci 20:19-26.

Krupnick JG, Benovic JL (1998) The role of receptor kinases and arrestins in G protein-coupled receptor regulation. Annu Rev Pharmacol Toxicol 38:289-319.

LeBars D, Menetrey D, Besson JM (1976) Effects of morphine upon the lamina $V$ type cells activities in the dorsal horn of the decerebrate cat. Brain Res 113:293-310.

Lefkowitz RJ (1998) G protein-coupled receptors. III. New roles for receptor kinases and beta-arrestins in receptor signaling and desensitization. J Biol Chem 273:18677-18680.

Li Y, Roerig SC (1999) Alteration of spinal protein kinase C expression and kinetics in morphine, but not clonidine, tolerance. Biochem Pharmacol 58:493-501.

Lowe JD, Celver JP, Gurevich VV, Chavkin C (2002) Mu opioid receptors desensitize less rapidly than delta opioid receptors due to less efficient activation of arrestin. J Biol Chem 277:15729-15735.

Mansour A, Khachaturian H, Lewis ME, Akil H, Watson SJ (1988) Anatomy of CNS opioid receptors. Trends Neurosci 11:308-314.
Matthes HW, Smadja C, Valverde O, Vonesch JL, Foutz AS, Boudinot E, Denavit-Saubie M, Severini C, Negri L, Roques BP, Maldonado R, Kieffer BL (1998) Activity of the delta-opioid receptor is partially reduced, whereas activity of the kappa-receptor is maintained in mice lacking the $\mu$-receptor. J Neurosci 18:7285-7295.

Mayer DJ, Price DD (1976) Central nervous system mechanisms of analgesia. Pain 2:379-404.

Narita M, Mizoguchi H, Tseng LF (1995) Inhibition of protein kinase C, but not of protein kinase A, blocks the development of acute antinociceptive tolerance to an intrathecally administered mu-opioid receptor agonist in the mouse. Eur J Pharmacol 280:R1-R3.

Negus SS, Henriksen SJ, Mattox A, Pasternak GW, Portoghese PS, Takemori AE, Weinger MB, Koob GF (1993) Effect of antagonists selective for mu, delta and kappa opioid receptors on the reinforcing effects of heroin in rats. J Pharmacol Exp Ther 265:1245-1252.

Noble F, Cox BM (1996) Differential desensitization of mu and delta opioid receptors in selected neural pathways following chronic morphine treatment. Br J Pharmacol 117:161-169.

Smith FL, Lohmann AB, Dewey WL (1999) Involvement of phospholipid signal transduction pathways in morphine tolerance in mice. $\mathrm{Br} \mathrm{J}$ Pharmacol 128:220-226.

Sora I, Takahashi N, Funada M, Ujike H, Revay RS, Donovan DM, Miner LL, Uhl GR (1997) Opiate receptor knockout mice define mu receptor roles in endogenous nociceptive responses and morphine-induced analgesia. Proc Natl Acad Sci USA 94:1544-1549.

Stone LS, MacMillan LB, Kitto KF, Limbird LE, Wilcox GL (1997) The $\alpha 2$ a adrenergic receptor subtype mediates spinal analgesia evoked by $\alpha 2$ agonists and is necessary for spinal adrenergic-opioid synergy. J Neurosci 17:7157-7165.

Trujillo KA, Akil H (1991) Inhibition of morphine tolerance and dependence by the NMDA receptor antagonist MK-801. Science 251:85-87.

Vanderah TW, Suenaga NM, Ossipov MH, Malan Jr TP, Lai J, Porreca F (2001) Tonic descending facilitation from the rostral ventromedial medulla mediates opioid-induced abnormal pain and antinociceptive tolerance. J Neurosci 21:279-286.

Whistler JL, von Zastrow M (1998) Morphine-activated opioid receptors elude desensitization by beta-arrestin. Proc Natl Acad Sci USA 95:9914-9919.

Yaksh TL (1997) Pharmacology and mechanisms of opioid analgesic activity. Acta Anaesthesiol Scand 41:94-111.

Zeitz KP, Malmberg AB, Gilbert H, Basbaum AI (2001) Reduced development of tolerance to the analgesic effects of morphine and clonidine in PKC gamma mutant mice. Pain 94:245-253.

Zhang J, Ferguson SS, Barak LS, Bodduluri SR, Laporte SA, Law PY, Caron MG (1998) Role for G protein-coupled receptor kinase in agonist-specific regulation of mu-opioid receptor responsiveness. Proc Natl Acad Sci USA 95:7157-7162.

Zhang L, Yu Y, Mackin S, Weight FF, Uhl GR, Wang JB (1996) Differential mu opiate receptor phosphorylation and desensitization induced by agonists and phorbol esters. J Biol Chem 271:11449-11454. 